\title{
NOMADIC AND SEDENTARY LIFE IN THE TIME OF PROPHET MUHAMMAD
}

\author{
Alwi Alatas, ${ }^{*}$ Hassan Suleiman ${ }^{* *} \&$ Sofiah Samsudin ${ }^{* * *}$
}

\begin{abstract}
The Bedouins who live nomadically have existed for a long time in the desert region of Arabia. They existed before and during the time of Prophet Muhammad (peace be upon him), when the cities in Arabia were still limited in number and level of population. They led a pastoralist life by herding livestock, especially camels. The Bedouins often appear in stories relating to Prophet Muhammad (PBUH), usually anonymous, with their typical characters of rudeness, discourtasy and lack of knowledge. They came to Makkah and Madīnah from time to time. Sometimes they involved in tribal warfare among themselves or against the emerging Islamic sovereignty. Urban society may play an important socio-political role and has more prominent leadership in the region, but the existence of the Bedouin society cannot be said to be unimportant in the structure of society at that time. Understanding the characteristics and the relation between the Bedouins and the sedentary people is actually important to understand the development of society and civilization, as suggested by the explanation of Ibn Khaldūn in his Muqaddimah. The objective of this study is to elucidate the characteristics of nomadic and sedentary societies and the relationship between the two in the era of the Prophet (PBUH) as well as the Islamic attitude towards these two patterns of life. This research is a historical study that uses the Qur'an and Hadīth as its main sources.
\end{abstract}

Keywords: Arabia, Bedouin, nomadic life, Prophet Muhammad, sedentary life, urban

\section{Introduction}

The nomadic society, the Bedouins, had existed in Arabia long before the emergence of Islam in the region and still exists today. Their existence is supplied by the geographical conditions of the desert of the Arabian Peninsula and the pastoral life that forms their livelihood. When Prophet Muhammad (peace be upon him) grew up in Makkah, nomadic and semi-nomadic life still characterized many inhabitants in Arabia, while sedentary societies that reached an urban level were still very limited. Makkah itself in the $6^{\text {th }}$ century was one of the largest and most important cities in Arabia, at least in terms of its central position in the Hejaz and its important position on the economic and trade routes in the region. The inhabitants of this city represented a more complex culture and civilization in the Hejaz and Nejd regions, although in the outer regions larger civilizations existed, especially the Byzantine and the Persian.

Sedentary society, as explained by Ibn Khaldūn, is an advanced stage of nomadic life. Although the standard of living of the Bedouins is very simple and may not be included in what is now defined as civilization, it does not mean that their existence is not important. Actually, between the Bedouins and the sedentary people there are inseparable reciprocal relationships, especially in the past. Both are interrelated elements of the social, economic, and political structure of sandy Arabia. Bedouin people are the basic hitorical ingredients for a settled society, while the sedentary people can look at nomadic life as a primordial reflection that at any difficult time may pull them back into it.

The life of Prophet Muhammad (PBUH) and his main followers was indeed more concerned with the settled society. However, Bedouins repeatedly appear in historical insertion, and even then become an important part of a new wave of history, as the evidence of their inseparable life from their urban counterparts. The transformation of nomadic society into settled society usually reflects a vital development in certain civilizations, especially in the past. Since the appearance of the Prophet in Hejaz in the early $7^{\text {th }}$ century had marked the start of Islamic civilization, it is important to understand how

\footnotetext{
* Alwi Alatas (Corresponding Author), Assistant Professor, Department of History \& Civilization, International Islamic University Malaysia. Email: alwialatas@iium.edu.my.

** Hassan Suleiman, Assistant Professor, Department of Fiqh \& Usul al-Fiqh, International Islamic University Malaysia. Email: abuxzubair@iium.edu.my.

*** Sofiah Samsudin, Assistant Professor, Department of Qur'an \& Sunnah, International Islamic University Malaysia. Email: sofiahs@iium.edu.my.
} 
Prophet Muhammad, and the Qur'an, viewed and regulated nomadic and sedentary life that would generally give direction for this new civilization. Therefore, this study wants to know what was the relationship between the settled and nomadic people during the time of the Prophet (PBUH) and what was the Prophet's attitude regarding this? This article will try to answer and explain things related to the questions above. This study is carried out through historical analysis regarding nomadic and sedentary life during the time of Prophet Muhammad, using especially the Qur'ān and Hadìth as its sources.

\section{On the Bedouin and the Sedentary People}

The Arabic word badawī means Bedouin, rural, and nomadic. ${ }^{1}$ The people are called the Bedouins and their ways of life and attitude differ from the sedentary people who live in the city. In general, badawi is considered at variance with the characteristics present in a sedentary setting. In his Lisān al-cArab, Ibn Mandzur defines this word as khiläf al-hadar, which means the opposite of city or urban. The word badawi is also associated with the desert. The words bädiyah means desert and badāwah desert life. ${ }^{2}$

Arabia is not the only region that contains nomadic and sedentary categories of society, and the middle category between the two or semi-nomadic, but its unique geographical conditions make this region seem to have preserved the existence of nomadic and semi-nomadic inhabitants to modern time, resisting, at least until so far, a complete transformation of the society into sedentary living. Until now, in Saudi Arabia we can still find Arab Bedouins, even though the government has been trying to encourage them to leave their nomadic live. In 1974, for example, the Bedouin population in Saudi Arabia was around $27 \%$ of the country's population. ${ }^{3}$ A Reuter article that quotes several experts in the beginning of 2012 suggests that in Saudi Arabia "nomadism as an economic structure is gone" and "only a handful of semi-nomads remain in the country's northern deserts". ${ }^{4}$ However, a study in 2012 informs that there were still around 2 million people that identify themselves as Bedouin in Saudi, out of its 21 million population. From that number, 200,000 or less are nomadic. ${ }^{5}$ The estimation number of the Bedouin in Syria was 900,000, without clear data reporting how many of them remain nomadic, ${ }^{6}$ while the population of the Bedouin in post-Saddam Iraq is around $10 \%$ of the total population. ${ }^{7}$

Tribal influence in Saudi Arabia has been much weaker since the foundation of the kingdom by Abdul Aziz ibn Saud in 1932. However, there is an indication that tribal feeling and identity has been reviving in the last two decades. ${ }^{8}$ A report by Sebastian Maisel in mid-2015 stated that "tribal groups from Saudi Arabia and the broader Arabian Peninsula have staged a socio-political comeback, claiming greater influence in the public sphere". ${ }^{9}$ Tribalism seems to grow stronger also in the course of the prolonged civil strife in Syria, Iraq and Yemen. However, extended discussion on tribalism and nomadism in modern Middle East is not the focus of this article. This only to show that until recently, tribal values and nomadic life still resist to be totally changed and absorbed through modern transformation in the Arab world.

The geographical situation of the Arabian Peninsula contains extensive desert with oases in a few places, and it has no rivers such as in Mesopotamia and Egypt. Occasionally, heavy rain pour and water flow through the valley, but quickly sink in the sandy ground. ${ }^{10}$ In the past, when technological measures were still very limited, this situation led to the constraints on agriculture, the slowness of urban growth, and therefore significantly reduced its probability to become a centre of great civilization. ${ }^{11}$ There is a view that the ancient Semites had inhabited this region since early ancient

\footnotetext{
${ }^{1}$ Hans Wehr (1966), A Dictionary of Modern Written Arabic, Wiesbaden: Otto Harrassowitz, p. 47.

${ }^{2}$ Ibn Manzūr (1119H), Lisān al-ćArab, Kairo: Dār al-Ma'ārif, p. 235.

${ }^{3}$ Mohammed Abdullah al-Wohaibi (1981), Nomads in al-Hejaz Province: A geographic Study of Nomads near the City of Taif, Master Thesis, Oklahoma State University, p. 11.

4 Angus McDowall (2012), "Saudi tribalism lingers for kingdom's settled Bedouin," Reuters, retrieved $8^{\text {th }}$ May 2020, https://www.reuters.com/article/uk-saudi-bedouin/saudi-tribalism-lingers-for-kingdoms-settled-bedouin-idUKTRE80O19Y20120125.

${ }^{5}$ Ruth Kark and Seth J. Frantzman (2012), "Empire, State and the Bedouin of the Middle East, Past and Present: A Comparative Study of Land and Settlement Policies," Middle Eastern Studies, Vol 48, No 4, p. 501.

${ }^{6}$ Kark and Frantzman (2012), "Empire, State and the Bedouin of the Middle East," p. 498.

${ }^{7}$ Kark and Frantzman (2012), "Empire, State and the Bedouin of the Middle East," p. 500.

${ }^{8}$ McDowall (2012), "Saudi tribalism lingers for kingdom's settled Bedouin."

${ }^{9}$ Sebastian Maisel (2015), "The Resurgent Tribal Agenda in Saudi Arabia," The Arab Gulf States Institute in Washington, p. 1.

${ }^{10}$ Arthur Goldschmidt, Jr. (1991), A Concise History of the Middle East, Boulder: Westview Press, p. 23.

${ }^{11}$ It is true that Islam emerged in that region and become a great civilization, but the centre of this civilization would soon move to Syria and other regions.
} 
times. The shortage of economic resources offered by the region had pushed the growing population to migrate north and turned to Egypt and together with the Hamites created Ancient Egyptian civilization, while some others went to Mesopotamia and mingled with the Sumerians, helping to develop Mesopotamian civilization. ${ }^{12}$ If this view is to be accepted, then the region, of which the Bedouin life becomes one of its inseparable features, has considerably contributed to the birth of early civilizations while at the same time has been preserving its nomadism up to modern days. The residents of this peninsula had indeed migrated to other regions throughout their history, since Arabia did not allow the formation of high density, ${ }^{13}$ while this is a requirement for the advent and advancement of civilization. ${ }^{14}$ The spread of Islam later on to other regions might have also been encouraged by the climatic factor that motivated the Arab tribes to find new pastoral regions for their cattle; a factor which would remain unfeasible without strong religious unifying factor and urban leadership. ${ }^{15}$ The major influx of nomadic and semi-nomadic people have indeed occurred several times in history. They have migrated and conquered cities and empires, such as the case of the Arabs to the Mediterranean, and then, in turn, themselves were conquered by the Turks and the other tribal ethnics. ${ }^{16}$

Ibn Khaldun explains that Bedouin life is an earlier stage before it develops into sedentary life. In other words, this is an early form of civilization that marked with several characteristics, such as itinerant and humble living and satisfy with no more than basic needs, but generally desiring urban life and urban economy that go beyond the subsistence level. Thus, badawi is the basis or the beginning of hadhari, and vice versa hadhari is the next phase or a destination for nomadic life. ${ }^{17}$ Nomadic society, as well as sedentary society, is a natural group of people who follow such live because of their livelihood. Sedentary people usually have livelihoods relate to agriculture, crafts, and commerce, while nomadic people rely on animal husbandry that requires pastureland for their animals. ${ }^{18}$ In addition to the nomadic group who tend to move continuously and the sedentary group who lives in towns, there is also the semi-nomadic group who settles in a village but in certain seasons has to travel to find pastureland for their cattles. ${ }^{19}$ The semi-nomadic group usually lives as sheep breeders and herders, which at certain times demanded the herdsmen to get around within a certain distance in the desert, but will come back and stay in the village after that. While those who belong to the nomadic group have a main livelihood as cameleers. Camels demand the herdsmen to go further into the desert because only then the needs of these desert animals can be fulfilled. Consequently, these camel herders possess the most opposite features compared to the members of urban society. "Compared with sedentary people," Ibn Khaldūn writes, "they are on a level with wild, untamable animals and dumb beasts of prey." These are the ones who are mainly referred to as Bedouins. ${ }^{20}$ In a sense, this nomadic people retain their very existence because they follow their camels and their camels follow the desert. In some of his hadith, Prophet Muhammad (PBUH) actually describes the horse and camel breeders (ahl al-khayl wa-l-ibil) as having poorer personality compare to the sheep breeders (ahl al-ghanam), ${ }^{21}$ thus, in a way, corroborating Ibn Khaldūn's observation.

Although the habitat of camels is close to the desert and attach to the Bedouins, it does not mean the inhabitants of the city in the past were not familiar with camels. Camels were also important for city dwellers because sometimes they needed them for long trips. Merchants and leaders of the city sometimes have a number of camels cared for by the Bedouins. ${ }^{22} \mathrm{We}$ read, for example, about the two hundred camels belonged to cAbd al-Mutțalib which was seized by Abrahah when the latter approached Makkah to destroy the Kacbah. ${ }^{23}$ In the hadith, when explaining about zakat, the Prophet (PBUH) mentions the categories of camels which might also be generally known by the other city-dwellers: bint makhäd (one year old she-camel), ibn labün (two year old male camel), bint labün (two year old she-

\footnotetext{
${ }^{12}$ Philip K. Hitti (1985), History of the Arabs, Houndmills: Macmillan Education, pp. 10-11.

${ }^{13}$ Al-Wohaibi (1981), "Nomads in al-Hejaz Province: A geographic Study of Nomads near the City of Taif," p. 16.

${ }^{14}$ Christopher Scarre and Brian M. Fagan (1997), Ancient Civilizations, New York: Longman, p. 8.

${ }^{15}$ Gerhard Endress (1994), Islam: An Historical Introduction, Edinburgh: Edinburgh University Press, p. 75.

16 John Sabini (1976), “The World of Islam: Its Nomads, Its Cities," retrieved $3^{\text {rd }}$ February 2020, https://archive.aramcoworld.com/issue/197603/the.world.of.islam-its.nomads.its.cities.htm.

${ }^{17}$ Ibn Khaldūn (1978), An Introduction to History: The Muqaddimah, London: Routledge and Keagan Paul, pp. 92-93.

${ }^{18}$ Ibn Khaldūn (1978), An Introduction to History, pp. 91-92.

19 Al-Wohaibi (1981), "Nomads in al-Hejaz Province: A geographic Study of Nomads near the City of Taif," p. 11.

${ }^{20}$ Ibn Khaldūn (1978), An Introduction to History, pp. 92-93.

${ }^{21}$ Al-Bukhārī (1997), The Translation of the Meanings of Sahīh al-Bukhārī, Vol. 4, Riyadh: Darussalam, pp. 315-316, hadīth No. 3301. The horse and camel breeders are characterised by pride (al-fakhr) and arrogance (khuyalä'), while the sheep breeders by calm (al-sakinah).

${ }^{22}$ Donald P. Cole (2003), "Where Have the Bedouin Gone?" Anthropological Quarterly, Vol. 76, No. 2, pp. $235-267$ \& 239.

${ }^{23}$ Ibn Hishām (1990), Al-Sīrah al-Nabawiyyah, Vol. 1, Dār al-Kitāb al-cArabī, pp. 64-65.
} 
camel), hiqqah (three year old she-camel), dan jadha cah (four year old she-camel). ${ }^{24}$ In the pre-Islamic era, there were religious categorizations of camels like al-bahìrah, or a she-camel whose milk was for the idols alone, and al-sa' $i b a h$, which was set free for the idols. ${ }^{25}$ These terms and rules are certainly known by the city dwellers. In fact, it was made, or endorsed and popularized, by the leader of Makkah in the past, because that city was the center of religious rituals in the region and its religious regulations became a reference for the surrounding society. These state of affairs more or less reinforce the description given by Tarif Khalidi about the nature of the cities in the Hejaz at that time which still had strong connection with the nomads of the desert. ${ }^{26}$

The Bedouin is usually called with the word $a$ rab, a word that indicates the origin of the Arab community in the region. cUmar ibn al-Khattāb once said that the Bedouins are "the origin of the Arabs and the material of Islam (așl al-carab wa māddah al-Isläm). ${ }^{, 27}$ This is generally in line with Ibn Khaldūn's explanation about the Bedouin's existence as being earlier to sedentary people. ${ }^{28}$ Some orientalists go further to suggest that the word $c A r a b$ has a connection with the Hebrew word abhar which means to move or to pass, ${ }^{29}$ thus pointing to the primordial characteristic of this people.

The association between the Arab people in ancient time with their camels is proverbial. An Assyrian inscription in 854 B.C., for example, mentions about an Arab leader who led a group of people riding a thousand camels fighting against Shalmaneser III in the Syrian border. ${ }^{30}$ At other times, these Arabs, which usually recorded as Aribi, Arabu, or Urbi, were forced to submit to the Assyrian conquerors and to give up some of their camels as tribute. The Arabs, again riding their camels, were also recorded as joining Xerxes army in his failure attempt to conquer Greece. ${ }^{31}$ The camels are highly important especially for the Arab Bedouins, to the extent that they used to call themselves as ahl al-baqr or the people of the camel. Almost every parts of this animal, even its dung and urine, are beneficial to them. The camel, to borrow Hitti's words, is "the Bedouin's constant companion, his alter ego, his foster parent". ${ }^{32}$

Their nomadic living, however, has suppressed them to the subsistence level, makes dates and water to become a precious possession. ${ }^{33}$ The harsh condition endured by these nomads gave birth to warlike groups, thus creating a relatively hostile environment and at the same time representing the economic structure of the desert. ${ }^{34}$ However, the Bedouins are also well known for certain good qualities, among which are hospitality to visitors and loyalty to friends. ${ }^{35}$ The Arab Bedouins are typically excel in Arabic language and they are very proud of it. This is actually one of the reasons why the Quraysh in the time of the Prophet (PBUH) sent their children for breastfeeding in the Bedouin's villages and the Prophet himself acknowledges that his fluency in language is because he is a Quraysh and he was nurtured during childhood in the village of Banu Sacd. ${ }^{36}$ In one occasion the Prophet (PBUH) recognized the beauty of a Bedouin language and said, "Some eloquence is magic and some poetry is wisdom."."77

The Bedouins are free people, not willing to submit to any authority other than their own tribe, yet they interact with their chief in the spirit of equality. ${ }^{38}$ Indeed, they lived scattered in the desert and stayed apart from the large tribes. "Individualism ... is so deeply ingrained that the Bedouin has never been

\footnotetext{
${ }^{24}$ Imām Muhammad bin Yazeed Ibn Majah al-Qazwīnī [henceforth Ibn Majah] (2007), English Translation of Sunan Ibn Mājah, Vol. 3, Riyadh: Darussalam, pp. 26-27, hadīth No. 1798.

${ }_{25}$ Al-Bukhārī (1997), The Translation of the Meanings of Șaḥ̄h al-Bukhārī, Vol. 4, p. 445, hadīth No. 3521.

${ }^{26}$ Tarif Khalidi (1996), Arabic historical thought in the classical period, Cambridge: Cambridge University Press, p. 2.

${ }^{27}$ Al-Bukhārī (1997), The Translation of the Meanings of Șahīh al-Bukhārī, Vol. 5, p. 46, hadìth No. 3700. This is part of ‘Umar's advice to do good to the emigrants, the anșār, and also the Bedouins, a few days before he died after being stabbed by a Persian slave.

${ }^{28}$ Ibn Khaldun (1978), An Introduction to History, p. 93.

${ }^{29}$ J.J. Saunders (2002), A History of Medieval Islam, London: Routledge, p. 3; Bernard Lewis (1966), The Arabs in History, New York: Harper Torchbooks, pp. 10-11.

${ }^{30}$ Saunders (2002), A History of Medieval Islam, p. 5

${ }^{31}$ Hitti (1985), History of the Arabs, p. 21; see also Lewis (1966), The Arabs in History, p. 11.

${ }^{32}$ Hitti (1985), History of the Arabs, pp. 21-22.

${ }^{33}$ Hitti (1985), History of the Arabs, p. 19.

${ }^{34}$ Hitti (1985), History of the Arabs, p. 25; Goldschmidt (1991), A Concise History of the Middle East, p. 23.

${ }^{35}$ Hitti (1985), History of the Arabs, p. 25.

36 cAbd al-Raḥmān al-Suhaylī (1967), Al-Raw ḍ al-Unuf fì Sharḥ al-Sīrah al-Nabawiyyah li-Ibn al-Hishām, Vol. 2, Cairo: Maktabah Ibn Taymiyyah, p. 167.

${ }^{37}$ Imām Hāāiz Abu Dawud Sulayman bin Ashcath [henceforth Abu Dawud] (2008), English Translation of Sunan Abu Dawud, Vol. 5, Trans. Nasiruddin al-Khattab, Riyadh: Darussalam, p. 362, hadìth No. 5011.

${ }^{38}$ Hitti (1985), History of the Arabs, p. 28.
} 
able to raise himself to the dignity of a social being of the international type ...."39 They simply do not like to live within social regulations that would restrict their freedoms. This state of affairs is naturally very much reluctant to the drive for the formation of expanded urban civilization under one rule, something that must be addressed carefully and negotiated by the urban leaders in the past through a confederation system or through cooperative agreements with the tribal chiefs. In general, and for ages, the Bedouins have stubbornly refused to change - those who decide to change will move to a city and live sedentarily. "In the Fertile Crescent empires have come and gone, but in the barren wastes the Bedouin has remained for ever the same." 40 Thus, Leopold Weiss - then Muhammad Asad after his conversion to Islam - is not exaggerating when he looked at an Arab Bedouin standing in the distance in Jerusalem in the first quarter of the twentieth century and felt as if he was looking at a Davidic warrior of the ancient Jewish stock, ${ }^{41}$ not, for our context, in the sense of the closeness between the Arab and the ancient Jews, rather of the timelessness of the Bedouin. Along with the modernization process in many Middle Eastern countries in the last half century, Bedouin societies seem to face greater challenge than ever before, which has forced considerable changes in their social and economic lives, that make them feel no longer like a true Bedouin. Despite those changes, "some Bedouin continue to be mobile and are still out on the range. ${ }^{42}$

Between nomadic and sedentary societies, there is a symbiotic relationship. This is particularly true for the period of our study. Some Bedouins with better economy sometimes decide to live permanently in villages or cities, and conversely those who live sedentarily but face socio-economic pressure may decide to return to nomadic life, so that these two patterns of life are not utterly unbridgeable. ${ }^{43}$ Bedouin people need products that they cannot produce themselves, such as dates and wheat, clothing, and weapons, but can be obtained in villages or cities, so that at certain times they will visit settled communities to obtain these various goods. At the same time, they can also offer their livestock and its derivative products, such as milk and wool, to the villagers or the city-dwellers. The Bedouins can also provide transportation services and security guarantees, with a certain wage, sustaining the travel between regions needed by the urban societies in carrying out their trade, which sometimes have to pass through zones that require tribal protection. ${ }^{44}$

In spite of connection and cooperation, there is opposite attraction between nomadism and sedentary life. The development of urban life toward more complex civilization requires the strengthening of an extended sedentary life, in addition to the disciplining of nomadic tribes who are accustomed to being free so they will subject to a more centralized rule, thus ensuring the realization of political and economic stability. If this happens, cities and villages will be increasingly integrated and in turn will develop into a country or a kingdom. Urban life will be increasingly complex and at the same time will develop its economy, sciences, defense system, and other elements of civilization. Conversely, nomadic societies will be relatively regulated, more submissive to the urban authority, and may become more marginalized.

However, at certain period, urban authority declined and its celebrated socio-economic stability was disintegrated. During such situation, nomadism would grow again, the Bedouins consolidated themselves, and authority shifted from urban leadership back to the tribal confederation, a gradual process which, of course, did not happened at once. It would led to the desertion of some settlements and the coercion of some of the urban population to migrate to better cities or to undergo nomadic life in the desert; in other words a process of bedouinization. Such situation had happened three centuries prior to the appearance of Islam in the Hejaz, due to the weakening of border powers, especially in South Arabia. Bedouin's raids in the border regions and tribal clashes occurred more frequently, forced peripheral settlements to leave agriculture and to accept pastoralism. ${ }^{45}$

It seems that the above process of bedouinization is also indicated by the Qur'ān when talking about the disintegration of Sabaean civilization in Yemen. Along with the story of the break of the Ma'rib

\footnotetext{
${ }^{39}$ Hitti (1985), History of the Arabs, p. 24.

${ }^{40}$ Hitti (1985), History of the Arabs, p. 24.

${ }^{41}$ Muhammad Asad (2004), The Road to Mecca, New Delhi: Islamic Book Service, p. 91.

${ }^{42}$ Cole (2003), "Where Have the Bedouin Gone?" p. 258.

${ }^{43}$ Hitti (1985), History of the Arabs, p. 23; Khalidi (1996), Arabic historical thought in the classical period, p. 2.

${ }^{44}$ Fred M. Donner (1999), "The Role of Nomads in the Near East in Late Antiquity (400-800 C.E.)," in F.E. Peters (ed.), The Arabs and Arabia on the Eve of Islam, Aldershot: Ashgate, p. 24.

${ }^{45}$ Ira M. Lapidus (1988), A History of Islamic Societies, Cambridge: Cambridge University Press, p. 17.
} 
dam (sayl al-carim), it also mentions about the changing urban situation in the region from the spread of settlements with linked roads between their cities and "the blessed cities", with security and stability, to the total dispersion of the society (Saba' [34]: 18-19). According to Tafsìr al-Qurtubī the blessed cities mentioned in that verse are located in al-Shām, and between Yemen and those regions, during the peak of the Sabaean era, there were a number of villages and cities (qaryah, p. qurā) with markets and connected roads, in and through which people could securely take a rest or spend the night and pass without a need to bring a lot of provisions. ${ }^{46}$ In other words, they did not need to spend the night in the desert in their long journey between Yemen and al-Shām. This illustrated the development of civilization and sedentary life, the realization of economic stability and the creation of security, and the reduction of, or at least the submission of, nomadic society. But the situation changed after that, following the Qur'ànic narration, as a punishment by God because of the people's ingratitude. The civilization in South Arabia declined, its political stability shattered, and its economy crumbled. The people were then dispersed, the society was torn apart, and livelihood had become very hard. Thus, the region "between them (the Sabaean in Yemen) and al-Shām had turned into waterless desert and sandy land through which they had to ride camels and need to prepare provisions". ${ }^{47}$ This clearly describes the disappearance of settlements and the conversion of many villages and towns into desert, which consequently would lead to the revitalization of nomadic life.

When the urban supremacy in South Arabia had been losing its confidence as it approached the end of the sixth century, the powers of the Arab kingdoms in North Arabia, Ghassan and Lakhm, were also waning due to the reduced support of or gradual takeover by each of their superior empires, the Byzantine and the Persian. However, such situations had spared Makkah in the Hejaz. ${ }^{48}$ Makkah was the most important town in Hejaz at that time. The other few, if not the only, important settlements in this region were Țā'if and Yathrib (later Madīnah).

Settlements in ancient times usually emerged around water - more attractively rivers, but in the case of Arabia mostly springs - which enabled the population to develop agriculture that expanded later into craft and commerce. Makkah arose around the spring of Zamzam, but it does not lead to agriculture. However, the existence of a shrine, the Kacbah, which attracted yearly pilgrimage from the surrounding regions had allowed commerce to grow and aided its position as a strong urban centre in that region. Makkah is actually not entirely devoid of agriculture, if we consider its attachment to the adjacent Țâ' if, both are called as two cities (qaryatayn) by the Qur'ān (Al-Zukhruf [43]: 31). ${ }^{49}$ Ṭâ' 'if is an agricultural town close to Makkah that share the pilgrimage commerce of the latter city, of which Makkah seems to have a share in its agricultural produces as well. The Prophet (PBUH), for example, had entered a walled garden of grapes in his way to Makkah - about three miles from Țā'if - after his unsuccessful attempt to get support from the Țā'if leaders. The garden belonged to Ibn Rabī cah brothers, two leaders of Makkah. ${ }^{50}$ It is interesting that in another instance when the Prophet (PBUH) told a story about an inhabitant of Paradise doing agricultural activity in Paradise, because he like to do so, a Bedouin commented that the person must be a Quraysh or an anșar - the tribes that were originally from or based in Makkah or Madīnah - because they are farmers (așhāb al-zar ), while the Bedouins are not farmers. ${ }^{51}$

The number of population in Makkah was not very big, around 10,000 to 15,000 according an estimation, and its urban status was still relatively fragile. ${ }^{52}$ The leaders of the city prior to and during the Prophet's time was the Quraysh, the Prophet's tribe and the tribe that claims lineage to Ismācīl the son of Ibrāhīm, but they needed to ensure peaceful settlement with the other tribal leaders in the region.

\footnotetext{
${ }^{46}$ Abū Abd Allāh Muḥammad ibn Aḥmad Abī Bakr al-Qurțubī (2006), al-Jāmic al-Aḥkām al-Qur'ān, Vol. 17, Beirut: al-Resalah, pp. 298299.

${ }^{47}$ Al-Qurțubī (2006), al-Jāmic al-Ahkām al-Qur'ān, p. 300. Abu Dawud narrated a hadīth about a deputation of Abyaḍ ibn Hammāl, called by the Prophet as the brother of Sabā', from Ma'rib region to Madīnah, mentioning how the people of Sabā' had been scattered (qad tabaddadat) and only a few still lived in Ma'rib (lam yabqa minhum illā qalīl bi-Ma'rib). See Abu Dawud (2008), English Translation of Sunan Abu Dawud, Vol. 3, p. 516, hadìth No. 3028. According to this book, the status of the hadìth is weak (ḍa $\bar{f}$ ).

${ }^{48}$ Lapidus (1988), A History of Islamic Societies, pp. 16-17.

49 The scholars of the Qur'ān says that al-qaryatayn here is Makkah and Ṭā'if. Al-Qurțubī (2006), al-Jāmic al-Ahkām al-Qur'ān, Vol. 19, p. 36; Abū al-Fidā’ Ismā̄īl Ibn Kathīr (1999), Tafsīr al-Qur'ān al-cAz̄ìm, Vol. 7, Riyadh: Dār Ṭaybah li-1-Nashr wa-l-Tawzīc, p. 225; Al-Ṭabarī (1994), Tafsīr al-Tabarī, Vol. 6, Beirut: Mu'assasah al-Risālah, p. 519.

${ }^{50}$ Șafī al-Raḥmān al-Mubārakfūrī (2007), Al-Raḥīq al-Makhtūm, Qațar: Wizārah al-Awqāf wa-1-Shu'ūn al-Islāmiyyah, pp. 125-126; Ibn Hishām (1990), Al-Sīrah al-Nabawiyyah, vol. 2, Beirut: Dār al-Kitāb al-cArabī, p. 68-69.

${ }^{51}$ Al-Bukhārī (1997), The Translation of the Meanings of Șah̄ị al-Bukhārī, Vol. 3, p. 308, hadīth No. 2348. However, the Bedouin might mean the Quraysh here as the Muslim migrants to Madīna and their new profession in that city, rather than their general profession in Makkah.

${ }^{52}$ Khalidi (1996), Arabic historical thought in the classical period, p. 2.
} 
As the urban leader, the Quraysh's rules would became the main reference for the neighboring people. This is particularly true for hajj or pilgrimage that attracted many people to Makkah every year. A nomadic tribe, Banū Fazārah, for example, had to follow the Quraysh's regulations of pilgrimage during the pre-Islamic period and the Quraysh had the right to their slaughtered animals. ${ }^{53}$

Several markets were open in and around Makkah during the pilgrimage, gave prominence to that city as a commercial center. The traders of Makkah also expanded their commercial activities abroad, especially to al-Shām. Their regular coming to al-Shām had been brought to the Byzantine's attention, as the contemporary sovereign of the region, so when the Byzantine emperor later received a letter from the Prophet (PBUH), he demanded a number of Arab traders from the Prophet's region, happened to be in the market of Jerusalem, to be invited to his court in that city. ${ }^{54}$ This commercial activity or longdistance trade, along with the presence of urban center, provide signs of civilization. ${ }^{55}$ However, several other important characteristics of civilization, like the existence of state, full-time specialization of labour, sciences (Astronomy, Mathematics), and writing, were relatively absence or very limited in Makkah and the other Hejaz towns. The Prophet (PBUH) himself said, "We are an illiterate nation (ummatun ummiyyatun); we neither write nor know accounts; the month is like this and this (sometimes of 29 days, sometimes of 30 days). ${ }^{" 56}$ This shows that the sedentary life in that region was still not fully developed during that era.

\section{The Bedouin, Sedentary Life, and the Prophet (PBUH)}

One day, in the year of the conquest of Makkah or in the ninth year of Hijrah, a group of Bedouins from the Banū Asad ibn Khuzaymah came to the Prophet (PBUH). They stated before the Prophet (PBUH) that they are believers, as if they had given benefit to the Prophet (PBUH) with their status as Muslims. The Qur'ān criticises them, “... You have not [yet] believed; but say [instead], 'We have submitted,' (to Islam), '...." (Al-Hujurāt [49]: 14) and it also says " Do not consider your Islam a favour [to the Prophet] ..." (A-Hujurāt [49]: 17). Those bedouins, in the view of the Qur'ān, had not yet believed. Their behavior was driven by opportunistic tendencies. ${ }^{57}$

The Bedouins are mentioned several times in the Qur'ān, usually with the word a crab, and more often not with positive judgment. In the other verses, this time related to the Hudaybiyyah incident, the bedouins are rebuked by the Scripture. They did not follow the Prophet (PBUH) for cumrah to Makkah and made excuses, while secretly they were prejudiced against the Prophet and the believers (Al-Fath [48]: 11-12). There is a difference of opinion among the commentators of the Qur'an about who the Bedouins referred to in these verses. ${ }^{58}$ One narration mentions, as stated by Ibn cAbbās and Mujāhid, that they were the Bedouins around Madinnah from the tribes of Ghifār, Aslam, Muzaynah, Juhaynah, Ashjac, and al-Dīl. These verses - as well as the previous verses in Surah al-Hujurāt - characterise certain groups of Bedouins as hypocrites, because they display something that is contrary to what is in their hearts. ${ }^{59}$

In Surah al-Tawbah, the criticism is no less definite. The Qur'ān describes them as "stronger in disbelief and hypocrisy" (asyaddu kufran wa nifäqan), "consider what they spend as a loss" and "await for you turns of misfortune," means expecting the Prophet's misfortune (Al-Tawbah [9]: 97-98). According to al-Ṭabarī, those Bedouins had "the hardest heart" (aqsā qulüban) and "the least knowledge of the rights of Allah" (aqallu cilman bi-huqūq Allāh) and they rarely interacted with good people (ahl al-khayr). They are, to put more precisely, worse in disbelief and hypocrisy in comparison to the urban

\footnotetext{
${ }^{53}$ Meir Kister (1986), "Mecca and the Tribes of Arabia: Some Notes on Their Relations," in M. Sharon (ed.), Studies in Islamic History and Civilization in Honour of Professor David Ayalon, Leiden: E.J. Brill, pp. 33-34.

${ }^{54}$ Al-Mubārakfūrī (2007), Al-Rah̄īq al-Makhtūm, p. 356.

${ }^{55}$ For the characteristics of civilization, see Scarre \& Fagan, Ancient Civilizations, pp. 6-7.

${ }^{56}$ Al-Bukhārī (1997), The Translation of the Meanings of Șahịh al-Bukhārī, Vol. 3, p. 88, hadīth No. 1913.

${ }^{57}$ Al-Qurțubī (2006), al-Jāmi cal-Ahkām al-Qur'ān, Vol. 19, pp. 420-421; Abū al-Hasan cAlī ibn Ahmad al-Wālidī (1991), Asbāb Nuzūl alQur'ān, Beirut: Dār al-Kutub al-cIlmiyyah, p. 412; Jalāl al-Dīn al-Suyūṭī (2002), Lubāb al-Nuqūl fì Asbāb al-Nuzūl, Beirut: Mu'assasah alKutub al-Thaqqāfiyyah, p. 243; Ibn Kathīr (1997), Tafsīr al-Qur'ān al-cAzìm, Vol. 8, p. 389. There is also a narration which states that these Bedouins were the same people as mentioned in Surah al-Fath as will be discussed later.

${ }^{58}$ Ibn Kathīr (1997), Tafsīr al-Qur'ān al-cAzìm, Vol. 8, p. 338.

${ }^{59}$ Al-Qurțubī (2006), al-Jāmical-Ahkām al-Qur'ān, Vol. 19, pp. 306-307.
} 
population. ${ }^{60} \mathrm{Al}-\mathrm{Qurtub} \overline{1}$ adds that they are the rudest in speaking (ajfā qawlan) and coarsest in nature (aghlazu tabcan). ${ }^{61}$

So far al-Qur'ān does not speak positively about the Bedouins and it seems they have lower status compare to the sedentary people. Indeed, they are not equal in certain cases: the Bedouins have no right to booty, their testimony against the sedentary people is invalid, and they cannot lead the prayer for the townsmen. However, there are exceptions for those who join jihād and have sufficient religious knowledge to receive booty, to give testimony and to lead prayer. ${ }^{62}$ The reason for their lower status in testimony is because most of them are weak in terms of religion and morality and rarely have the opportunity to learn. ${ }^{63}$ The case is also the same for prayer, as could be seen for example in the case of a Bedouin speaking in the middle of a congrational prayer, so when the payer ended the Prophet explained to him gently not to do so in the future. ${ }^{64}$

The criticism of the Qur'ān against the Bedouins, especially in the last verses discussed, should not be seen as a discrimination between different sections of the society. The inclusion of the previous and the subsequent verses will give better understanding about this issue. First, the tendency to disbelief is actually also present among the sedentary people in Madinah as mentioned in the previous verses. ${ }^{65}$ Thus, the Bedouins are not alone in this, though the case seems more prevalent among them. The hypocrites of Madīnah, according to the Qur'ān, actually hoped to stay outside of the city along with the Bedouins during the siege of the city in the Battle of Khandaq (Al-Ahzāb [33]: 20). Second, in the succeeding verses, the Qur'ān speaks positively about this group of people. It says that among the Bedouins there "are some who believe in Allah and the Last Day and consider what they spend as means of nearness to Allah and of [obtaining] invocations of the Messenger," and one day God will admit them into His mercy (Paradise) (Al-Tawba [9]: 99). This verse refers to Banū Muqarrin within the tribe of Muzaynah. ${ }^{66}$ Now, the Qur'ān testifies that not all of the Bedouins are bad and hypocritical. Some of them are actually good. Third, this is not less important, al-Qur'ān actually points to the reasons why many Bedouins tend to disbelief. It is because their harsh and remote living has shaped their coarse nature and halted them from the access to knowledge and religion. ${ }^{67}$

The Bedouins also appear in many places in the Prophet's Hadīth. The companions used to mention them anonymously, only as Bedouins. Their attendances were recognised, but their names and standing were frequently not present. They were generally known for their rudeness and lack of manners, but the Prophet (PBUH) interacted with them patiently. More than once the Bedouins came to the Prophet (PBUH) and impolitely demanded alms, while forcing the Prophet (PBUH) to move under a tree, ${ }^{68}$ or pulling his garment violently, ${ }^{69}$ or rejecting his glad tidings, ${ }^{70}$ and the Prophet (PBUH) would respond calmly, usually with smile. Another Bedouin came and spoke harshly to the Prophet, asking for the repayment of his debt. ${ }^{71}$ In one occasion, the Prophet (PBUH) was sitting and eating with six companions, then a Bedouin entered and finished the food in two bites only. "If he had said Bismillah," the Prophet said, "it would have sufficed you all." $" 72$ In another occasion, consecutively a girl and a Bedouin were rushing to take food, but the Prophet (PBUH) held their hands and explained that it was actually the devil that made them in a hurry to eat without mentioning Allah's name to enable it participating in eating. ${ }^{73}$ A Bedouin received the Prophet's visit when he was sick, but repudiated the

\footnotetext{
${ }^{60}$ Al-Țabarī, Tafsīr al-Ṭabarī, Vol. 4, p. 151.

${ }^{61}$ Al-Qurțubī (2006), al-Jāmic al-Ahkām al-Qur'ān, Vol. 10, p. 338.

${ }^{62}$ Ibid., pp. 338-339. Regarding the share of booty also Imām Abul Hussain Muslim bin al-Hajjaj [henceforth Muslim] (2007), English Translation of Sahīh Muslim, Vol. 5, Riyadh: Darussalam, pp. 16-18, hadīth No. 4522; Ibn Majah (2007), English Translation of Sunan Ibn Mājah, Vol. 4, pp. 98-100, hadīth No. 2858; Abu Dawud (2008), English Translation of Sunan Abu Dawud, Vol. 3, pp. 262-264, hadīth No. 2612. Regarding the testimony see Ibn Majah (2007), English Translation of Sunan Ibn Mãjah, Vol. 3, , p. 356, hadīth No. 2367, the status of the hadīth is șahịh according to this book; Abu Dawud (2008), English Translation of Sunan Abu Dawud, Vol. 4, p. 186, hadīth No. 3602, the status is sahịh.

${ }^{63}$ Ibn Majah (2007), English Translation of Sunan Ibn Mājah, Vol. 3, 356.

${ }^{64}$ Abu Dawud (2008), English Translation of Sunan Abu Dawud, Vol. 1, pp. 544-545, hadīth No. 931, the status is hasan.

${ }^{65}$ Al-Qurtubī (2006), al-Jāmi c al-Ahkām al-Qur'ān, Vol. 10, pp. 337-338.

${ }^{66}$ Al-Qurțubī (2006), al-Jāmi cal-Aḥkām al-Qur'ān, Vol. 10, p. 342.

${ }^{67}$ Al-Qurtubī (2006), al-Jāmi cal-Ahkām al-Qur'ān, Vol. 10, pp. 339-340.

${ }^{68}$ Al-Bukhārī (1997), The Translation of the Meanings of Șaḥ̄h al-Bukhārī, Vol. 4, p. 237, hadīth No. 3148.

${ }^{69}$ Al-Bukhārī (1997), The Translation of the Meanings of Șaḥịh al-Bukhārī, Vol. 4, pp. 237-238, hadìth No. 3149; Muslim (2007), English Translation of Sahīh Muslim, Vol. 3, pp. 99-100, hadīth No. 2429.

${ }^{70}$ Al-Bukhārī (1997), The Translation of the Meanings of Ṣahīh al-Bukhārī, Vol. 5, pp. 373-374, hadīth No.4328; Muslim (2007), English Translation of Sahīh Muslim, Vol. 6, pp. 365-366, hadìth No. 6405.

${ }^{71}$ Ibn Majah (2007), English Translation of Sunan Ibn Mājah, Vol. 3, pp. 388-389, hadīth No. 2426, the status is hasan.

${ }^{72}$ Ibn Majah (2007), English Translation of Sunan Ibn Mājah, Vol. 4, p. 325, hadìth No.3264, the status is șahīh.

${ }^{73}$ Muslim (2007), English Translation of Sahīh Muslim, Vol. 5, pp. 367-368, hadìth No. 5259.
} 
Prophet's pray for his recovery. ${ }^{74}$ Another Bedouin peeped at the door gap of the Prophet's house. The Prophet (PBUH) took an arrow or a sharp stick and pointed it at the Bedouin as if to pierce his eyes so the Bedouin left straightaway. ${ }^{75}$ One other Bedouin urinated in the mosque and made the people angry, but the Prophet (PBUH) asked them not to disturb him and poured a bucket of water to clean it after that. ${ }^{76}$ In one occasion, a Bedouin came and felt astonished with the fact that the Prophet [PBUH] and the companions used to kiss their children - out of love - and stated that they, the Bedouins, do not kiss their children. To this, the Prophet only responded, "I cannot put mercy in your heart after Allah has taken it away from it.",77

Many of the Bedouins stood on the outer limits of Islam and as long as they remained like that, they could turn into a threat to it. In one hadith, the Prophet (PBUH) said, "From this side," pointing towards the east, "trials and afflictions (al-fitan) will appear. Rudeness (al-jafä') and lack of mercy (ghilaz al$q u l \bar{u} b$ ) are characteristics of the rural hedouins (ahl al-wabar) who are busy with their camels and cows (and pay no attention to religion). Such are the tribes of Rabīcah and Mudar." ${ }^{, 78}$ The term used in this hadìth for the Bedouins is not a rab or badawī, but ahl al-wabar. However, its meaning is approximately the same, which is nomadic people, being opposite to ahl al-madar or the people who live sedentarily. ${ }^{79}$

The above saying of the Prophet does not clarify what kind of affliction those Bedouins would commit. Apart from that, history shows that soon after the Prophet [PBUH] passed away, something bad occurred in the society. At the end of his life, the Prophet (PBUH) had "single-handedly ... brought peace to war-torn Arabia." ${ }^{" 80}$ Throughout the period of Madīnah, there was a steady transformation of the entire society from tribal to state system, which consequently forced the rural society to submit to urban authority. When Abū Bakr became the leader of the ummah, apostasy (riddah) and insubordination occurred in Arabia involving many leaders and members of the non-urban society. The death of the Prophet [PBUH] might be seen by the Bedouins as an end of the new centralized power that increasingly curbed their freedom, but they were wrong. ${ }^{81}$ Abu Bakr was decisive and fought against those who apostatized, until they return to Islam. "The desert had not seen the like of this violent battles during the lifetime of the Prophet." ${ }^{" 22}$ Abu Bakr successfully subdued the rebellion and restored the unity of the ummah $^{83}$

Makkah and Madīnah were the exceptions of the above occurrence, ${ }^{84}$ along with Ṭā'if. ${ }^{85}$ It is important to note, however, that hypocrites were still exist in Madīnah at that time, and Makkah and Țā'if at a moment were on the brink of apostasy, but soon decided to remain in Islam and loyal to the successor of the Prophet, thanks to Suhayl ibn cAmr ${ }^{86}$ and cUthmān ibn Abī al-cĀṣ al-Thaqafir ${ }^{87}$ for their vital roles in those respective cities. In contrast, something similar also happened in the rural areas. Despite most of the tribal and nomadic society revolted, few but significant members of that society were stick to Islam and actively supported the policy of the Muslim central authority ${ }^{88}$

In the period of Madinnah, the Prophet strongly recommended the rural people that accepted Islam to migrate to that city. ${ }^{89}$ There was a case when a Bedouin gave a pledge (baycah) to the Prophet (PBUH) and stayed in Madīnah, then fell sick and asked for the cancelation of his pledge, but rejected by the Prophet. Then he left Madīnah furtively and the Prophet said that "Madīnah is like a furnace, it

\footnotetext{
${ }^{74}$ Al-Bukhārī (1997), The Translation of the Meanings of Șaḥ̄ḥ al-Bukhārī, Vol. 4, pp. 491-492, hadīth No. 3616.

${ }^{75}$ Imam Muhammad bin Ismail al-Bukhari (1971), Manners in Islam: Al Adab Al Mufrad, Beirut: Dar Al-Kotob Al-ilmiyah, pp. 677-678.

${ }^{76}$ Al-Bukhārī (1997), The Translation of the Meanings of Șaḥ̄h al-Bukhārī, Vol. 1, p. 174, hadīth No. 219 \& 220.

77 Al-Bukhārī (1997), The Translation of the Meanings of Șaḥịh al-Bukhārī, Vol. 8, pp. 30-31, ḥadìth No. 5998. See also Muslim (2007), English Translation of Sahīh Muslim, Vol. 6, p. 170, hadith No. 6027.

${ }_{78}$ Al-Bukhārī (1997), The Translation of the Meanings of Șaḥ̄h al-Bukhārī, Vol. 4, p. 435, hadīth No. 3498.

${ }^{79}$ Wehr (1966), A Dictionary of Modern Written Arabic, p. 33 \& p. 1045.

${ }^{80}$ Karen Armstrong (2002), Islam: A Short History, New York: A Modern Library Chronicles Book, p. 23.

${ }^{81}$ Saunders (2002), A History of Medieval Islam, pp. 40-41.

${ }^{82}$ Muhammad al-Ghazali (1999), Fiqh-us-Seerah: Understanding the Life of Prophet Muhammad, Riyadh: International Islamic Publishing House, p. 502.

${ }^{83}$ Armstrong (2002), Islam: A Short History, p. 27.

${ }^{84}$ Ibn Kathīr (1998), Al-Bidāyah wa-l-Nihāyah, Vol. 9. Hajar, p. 440.

${ }^{85}$ Al-Mubārakfūrī (2007), Al-Rah̄īq al-Makhtūm, pp. 448-449.

${ }^{86}$ Ibn Hishām (1990), Al-Sìrah al-Nabawiyyah, Vol. 4, Dār al-Kitāb al-cArabī, p. 317.

${ }^{87}$ Al-Mubārakfūrī (2007), Al-Rah̄īq al-Makhtūm, pp. 448-449.

${ }^{88}$ Ali Muhammad Muhammad as-Sallaabee (n.d.), The Biography of Abu Bakr as-Siddeeq, Riyadh, Darussalam, p. 376.

${ }^{89}$ Muslim (2007), English Translation of Sahīh Muslim, Vol. 5, pp. 16-18, hadìth No. 4522.
} 
eliminates its impurities and purifies what is good." ${ }^{.90}$ In another occasion, a group of Bedouins from the tribes of cUkl and cUraynah came to the Prophet (PBUH) and embraced Islam. They were granted permission to stay outside Madinah because the climate of the city is not suitable for them. However, they soon apostated from Islam and killed the shepperd of the Prophet that went along with them. They were pursued and punished after that. ${ }^{91}$ Some others, however, migrated and survived in Madinnah. One of them, for example, did not want his share from the booty of Khaybar, or any other booty, and instead expected to be a martyr and went to paradise. Later he joined a battle and got martyrdom as he expected, which was shot by an arrow in his neck. ${ }^{92}$

As the rural people were encouraged to migrate to Madinnah, those who already lived in the city were also not allowed to go out and live with the Bedouins. Leaving the city and following a nomadic lifestyle tends to be seen as a sign of hypocrisy. Salamah ibn al-Akwar went out from Madinah after the killing of cUthmān ibn al-cAffān. He lived in al-Rabadhah and only came back to Madīnah few days before he passed away. Hajjāj had accused him of deserting Islam because of that, but Salamah said that the Prophet had allowed him to stay with the Bedouin in the desert. ${ }^{93}$ Actually, there is an exception given by the Prophet (PBUH) for the city-dwellers to live as a Bedouin during the time of tribulation, ${ }^{94}$ though most of the companions kept staying in the city during tribulation. Abu Dhar also moved to al-Rabadhah and stayed there until he passed away in the second half of cUthmān's reign. ${ }^{95}$

The above portrayal generally suggests that the Bedouin's environment was not really supportive for the development of Islam, at least compare to the sedentary setting. Islam urges people to seek knowledge, which is very difficult for those who live a nomadic life. It is problematic also for the Bedouins to perform certain religious practices, such as Jumcah prayer that requires a gathering of at least 40 persons. ${ }^{96}$ Thus, from an Islamic point of view, Bedouin life is discouraged, especially for those who already settled, but its very existence cannot be rejected. The Bedouins still have a share in religion, though sedentary life offer a fuller opportunity in religious application. The fact that after his migration the Prophet (PBUH) changed the name of Yathrib into Madīnah needs to be highlighted. Madinah has a meaning of "city" and is derived from the Arabic din or religion, ${ }^{97}$ thus signifies the strong relationship between the two. Syed Muhammad Naquib al-Attas gives a comment on this:

We must see the fact that al-Madinnah was so called and named because it was there that the true din became realized for mankind. There the Believers enslaved themselves under the authority and jurisdiction of the Holy Prophet (may God bless and give him Peace!), its dayyān; there the realization of the debt to God took definite form, and the approved manner and method of its repayment began to unfold.... We may further see that the City became, for the Community, the epitome of the socio-political order of Islam; and for the individual Believer it became, by analogy, the symbol of the Beliver's body and physical being in which the rational soul, in emulation of him who may God bless and give Peace!, exercises authority and just government. ${ }^{98}$

The discouragement from the Prophet (PBUH) for those who had already lived in Madīnah to return to nomadic life, in a way, could be seen as an effort to maintain and develop a strong and healthy state of Madīnah, besides the fact that urban life is more suitable for religious life as explained before. However, the Prophet (PBUH) let the process of urbanization run naturally and did not try to push all or most of the nomads to move to the city. At the same time, a simple life, which is the daily life of the nomads, is

\footnotetext{
${ }^{90}$ Muslim (2007), English Translation of Sahīh Muslim, Vol. 3, pp. 529-530, hadīth No. 3355; Al-Bukhārī (1997), The Translation of the Meanings of Șahīh al-Bukhārī, Vol. 3, p. 74, hadīth No. 1883.

${ }_{91}$ Al-Bukhārī (1997), The Translation of the Meanings of Șahīh al-Bukhārī, Vol. 5, pp. 309-310, hadīth No. 4192.

${ }^{92}$ Maulana Muhammad Yusuf Kandhlawi (1989), Hayatus Sahabah: The Lives of the Sahabah, Vol. 1, New Delhi: Idara Isha'at-E-Diniyat, pp. 640-641.

${ }_{93}$ Al-Bukhārī (1997), The Translation of the Meanings of Șahịh al-Bukhārī, Vol. 9, p. 139, hadīth No. 7087.

${ }^{94}$ Abu Dawud (2008), English Translation of Sunan Abu Dawud, Vol. 4, p. 499, hadìth No. 4267, the status is șahịh. Abu Dawud put the hadith under the subtitle "the concession allowing living as a Bedouin during the tribulation."

${ }_{95}$ Al-Bukhārī (1997), The Translation of the Meanings of Șahīh al-Bukhārī, Vol. 2, p. 283, hadīth No. 1406. He did this with cUthmān's consent.

${ }^{96}$ Al-Wohaibi (1981), "Nomads in al-Hejaz Province: A geographic Study of Nomads near the City of Taif," p. 15. The Bedouins themselves see the religion as a sedentary religion.

${ }^{97} D_{\bar{l}} \mathrm{n}$ as understood by Islam, however, is much comprehensive than "religion" as understood by Western people. See chapter three of Syed Muhammad Naquib al-Attas (1993), Islam and Secularism, Kuala Lumpur: International Institute of Islamic Thought and Civilization (ISTAC).

${ }^{98}$ Al-Attas (1993), Islam and Secularism, p. 53, footnote No. 42.
} 
practiced and encouraged by the Prophet, though a haläl fortune is certainly not prohibited in religion. The suggestion for humble living is actually beneficial to avoid the risk brought by the flourishing urban life, as later explained by Ibn Khaldūn, namely the occurrence of moral corruption within the society. ${ }^{99}$ In one hadith, the Prophet (PBUH) says that "al-badhädhah (shabbiness) is part of faith." ${ }^{100} \mathrm{Al}$ badhädhah means shabbiness, dirtiness, filth, untidiness, ${ }^{101}$ which at first impression is contradictory to the teaching of cleanliness in Islam. However, the Prophet (PBUH) was saying the above hadith when hearing the companions talked about the world (al-dunya) $)$, thus giving a context to that saying. The meaning of al-badhädhah here is most probably 'simplicity', emphasizing that simplicity or staying away from luxury is always the priority in Islam, even though they lead an urban life. However, there is another interpretation to the above hadith that it is specifically for the Bedouins, and not for the sedentary people. ${ }^{102}$ This interpretation provides religious space for the nomadic people, because their humble living in the desert tends to make them always in an unclean and untidy state.

The interaction between the inhabitants of the city of Medinah and the nomadic people in the Prophet's era in many occasions was relatively well. Sometimes the Bedouins asked the Prophet to pray for them, like the one asking for pray for rain during a famine, ${ }^{103}$ or even competed with the Prophet in a camel race. ${ }^{104}$ The Prophet (PBUH) also directed his companions to be gentle and caring to the Bedouins. For example, he prohibited the city-dwellers to sell goods on behalf of the Bedouins. ${ }^{105}$ The city-dwellers were of course more in control of trade and might be tempted to take advantage for himself, to the expense of the Bedouins. cUmar ibn al-Khattāb during his reign also paid attention and was very helpful to the Bedouin villages during famine. ${ }^{106}$ The relation between the two, as tought by the Prophet (PBUH), is actually based on religion and manners ( $a d a b)$ rather than on social or geographical position. Thus, in one occasion, after dringking a milk, the Prophet deliberately passed the tumbler of milk to a Bedouin in his right, and not to Abū Bakr, a prominent member of the society of Madīnah, who sat on his left, because this is the $a d a b$ in Islam. ${ }^{107}$

Some Bedouins actually possessed good characters and showed great interest to religious knowledge and guidance, despite their plainnes. A Bedouin once asked the Prophet (PBUH) about a deed that could bring him to paradise and the Prophet explained about the five pillars in Islam. The Bedouin then committed himself to those five deeds and would not add more, and the Prophet acknowledged him as a people of paradise. ${ }^{108}$ Another Bedouin, whose name al-Șubayy ibn Macbad, became a Christian before the time of Islam, which showed his interest in religion, and then became a Muslim and tried to learn about the procedures of hajj and umrah. Critcism from few people on his deed during hajj made him uneasy, so he went to Caliph cUmar who confirmed that his deed is in accordance to the sunnah of the Prophet. ${ }^{109}$

The Prophet (PBUH) even had a Bedouin friend, whose name is Zāhir. He is not handsome but the Prophet loves him. He used to come to Madinah and brought gifts from the desert for the Prophet (PBUH), and the Prophet would provide him with supplies from the city before he went back to the desert. One day, the Prophet saw him busy in the market of Madinnah, so the Prophet hugged him from behind and jokingly said to the people, "Who will purchase this slave?" Zāhir replied humbly that he is actually worthless (käsidan), but the Prophet denies that and testifies that he is actually precious in the sight of Allah. ${ }^{110}$ cUmar also has a bedouin friend and later on his son Ibn cUmar would be very kind and give several gifts when meeting with the son of that Bedouin on his way to Makkah. ${ }^{111}$ This shows good relationship between the urban and the nomadic society during the time of the Prophet and the companions.

\footnotetext{
${ }^{99}$ Ibn Khaldūn (1978), An Introduction to History, p. 94.

${ }^{100}$ Abu Dawud (2008), English Translation of Sunan Abu Dawud, Vol. 4, p. 447, hadīth No.4161, the status is hasan.

${ }^{101}$ Wehr (1966), A Dictionary of Modern Written Arabic, p. 48.

${ }^{102}$ As explained by Shaikh Hamza Yusuf, referring to a book by a Muslim scholar, but unfortunately so far I do not have the opportunity to refer directly to that book. See https://www.youtube.com/watch?v=ypUrjCuj0DU, retrieved 2 ${ }^{\text {nd }}$ February 2020.

${ }^{103}$ Al-Bukhārī (1997), The Translation of the Meanings of Șahịh al-Bukhārī, Vol. 2, pp. 47-48, hadīth No. 933.

${ }^{104}$ Al-Bukhārī (1997), The Translation of the Meanings of Sahīh al-Bukhārī, Vol. 4, p. 88, hadìth No. 2872.

${ }^{105}$ Al-Bukhārī (1997), The Translation of the Meanings of Șaḥịh al-Bukhārī, Vol. 3, pp. 262-263, hadīth No. 2274; Muslim (2007), English Translation of Sahīh Muslim, Vol. 4, p. 38, hadīth No. 3458.

${ }^{106}$ Al-Bukhari (1971), Manners in Islam: Al Adab Al Mufrad, p. 398.

${ }^{107}$ Al-Bukhārī (1997), The Translation of the Meanings of Sahịh al-Bukhārī, Vol. 3, p. 312, hadīth No. 2352.

${ }_{108}$ Al-Bukhārī (1997), The Translation of the Meanings of Șahịh al-Bukhārī, Vol. 2, pp. 277-278, hadìth No. 1397.

${ }^{109}$ Abu Dawud (2008), English Translation of Sunan Abu Dawud, Vol. 2, p. 374, hadīth No. 1799.

${ }^{110}$ Al-Tirmidzi (1988), Syama 'il Muhammadiyyah, third edition, Beirut: Dār al-Hadīth, p. 113.

${ }^{111}$ Muslim (2007), English Translation of Sahīh Muslim, Vol. 6, p. 421, hadīth No. 6513.
} 


\section{Conclusion}

The Bedouins in general had some characteristics that are not really ideal, especially from religious and civilisational point of view. Nomadic life or badāwah is less favoured in Islam, though it is not prohibited. Instead, sedentary life and hadārah is preferable and more in line with the aspiration of Islam, not in the sense of extravagance and individualistic lifestyle, but rather in the sense of better manifestation of $c_{i l m}$ (knowledge), imān (faith), and adab (good manners). Nomadic life is seen as less favourable because many of its people do not pay attention to religion and do not possess good manners. However, the Bedouins were not despised or discriminated by the urban Muslim society during the time of the Prophet (PBUH), but they were to be dealt with patient when any shortages were encountered and also to be protected their rights, while they might learn basic tenets of Islam and good manners. Finally, when a Bedouin comes forward with better characteristics than before, or than most of his colleagues, especially in the matters of faith and adab, then in fact he has no difference with a good urban Muslim. They are in fact brothers and in a positive mutual relationship, filled with love and trust.

\section{References}

Abu Dawud, Imām Ḥāfiz Sulayman bin Ashcath (2008), English Translation of Sunan Abu Dawud, Vol. 1, Riyadh: Darussalam.

Armstrong, Karen (2002), Islam: A Short History, New York: A Modern Library Chronicles Book.

Asad, Muhammad (2004), The Road to Mecca, New Delhi: Islamic Book Service.

Al-Attas, Syed Muhammad Naquib (1993), Islam and Secularism, Kuala Lumpur: International Institute of Islamic Thought and Civilization (ISTAC).

Al-Bukhārī (1997), The Translation of the Meanings of Șahịh al-Bukhārī, Vol. 1, Riyadh: Darussalam.

Al-Bukhārī (1997), The Translation of the Meanings of Șahīh al-Bukhārī, Vol. 2, Riyadh: Darussalam.

Al-Bukhārī (1997), The Translation of the Meanings of Șahịh al-Bukhārī̄, Vol. 3, Riyadh: Darussalam.

Al-Bukhārī (1997), The Translation of the Meanings of Șahịh al-Bukhārī̄, Vol. 4, Riyadh: Darussalam.

Al-Bukhārī (1997), The Translation of the Meanings of Șahīh al-Bukhārī̄, Vol. 5, Riyadh: Darussalam.

Al-Bukhārī (1997), The Translation of the Meanings of Șahịh al-Bukhārī, Vol. 8, Riyadh: Darussalam.

Al-Bukhārī (1997), The Translation of the Meanings of Șahīh al-Bukhārī, Vol. 9, Riyadh: Darussalam.

Al-Bukhari, Imam Muhammad bin Ismail (1971), Manners in Islam: Al Adab Al Mufrad, Beirut: Dar Al-Kotob Al-ilmiyah.

Cole, Donald P. (2003), “Where Have the Bedouin Gone?” Anthropological Quarterly, Vol. 76, No. 2.

Donner, Fred M. (1999), "The Role of Nomads in the Near East in Late Antiquity (400-800 C.E.)," in F.E. Peters (ed.), The Arabs and Arabia on the Eve of Islam, Aldershot: Ashgate.

Endress, Gerhard (1994), Islam: An Historical Introduction, Edinburgh: Edinburgh University Press.

Al-Ghazali, Muhammad (1999), Fiqh-us-Seerah: Understanding the Life of Prophet Muhammad, Riyadh: International Islamic Publishing House.

Goldschmidt, Arthur Jr. (1991), A Concise History of the Middle East, Boulder: Westview Press.

Hitti, Philip K. (1985), History of the Arabs, Houndmills: Macmillan Education. 
Ibn Hishām (1990), Al-Sīrah al-Nabawiyyah, Vol. 1, Beirut: Dār al-Kitāb al-cArab̄̄.

Ibn Hishām (1990), Al-Sīrah al-Nabawiyyah, Vol. 2, Beirut: Dār al-Kitāb al-cArab̄̄.

Ibn Hishām (1990), Al-Sìrah al-Nabawiyyah, Vol. 4, Beirut: Dār al-Kitāb al-cArab̄̄.

Ibn Kathīr (1998), Al-Bidāyah wa-l-Nihāyah, Vol. 9, Hajar.

Ibn Kathīr, Abū al-Fidā' Ismā̄īl (1999), Tafsīr al-Qur'ān al-cAzìm, Vol. 7, Riyaḍ: Dār Ṭaybah li-1Nashr wa-1-Tawzīc.

Ibn Kathīr, Abū al-Fidā’ Ismā̄īl (1997), Tafsìr al-Qur'ān al-cAzīm, Vol. 8, Riyāḍ: Dār Ṭaybah li-1Nashr wa-1-Tawzīc.

Ibn Khaldūn (1978), An Introduction to History: The Muqaddimah, London: Routledge and Keagan Paul.

Ibn Majah, Imām Muhammad bin Yazeed al-Qazwīnī (2007), English Translation of Sunan Ibn Mājah, Vol. 3, Riyadh: Darussalam.

Ibn Majah, Imām Muhammad bin Yazeed al-Qazwīnī (2007), English Translation of Sunan Ibn Mājah, Vol. 4, Riyadh: Darussalam.

Ibn Manzūur (1119H), Lisān al-cArab, Kairo: Dār al-Ma'ārif.

Kandhlawi, Maulana Muhammad Yusuf (1989), Hayatus Sahabah: The Lives of the Sahabah, Vol. 1, New Delhi: Idara Isha'at-E-Diniyat.

Kark, Ruth and Seth J. Frantzman (2012), "Empire, State and the Bedouin of the Middle East, Past and Present: A Comparative Study of Land and Settlement Policies," Middle Eastern Studies, Vol 48, No 4.

Khalidi, Tarif (1996), Arabic historical thought in the classical period, Cambridge: Cambridge University Press.

Kister, Meir (1986), "Mecca and the Tribes of Arabia: Some Notes on Their Relations," in M. Sharon (ed.), Studies in Islamic History and Civilization in Honour of Professor David Ayalon, Leiden: E.J. Brill.

Lapidus, Ira M. (1988), A History of Islamic Societies, Cambridge: Cambridge University Press.

Lewis, Bernard (1966), The Arabs in History, New York: Harper Torchbooks.

Maisel, Sebastian (2015), "The Resurgent Tribal Agenda in Saudi Arabia," The Arab Gulf States Institute in Washington.

McDowall, Angus (2012, January 25), "Saudi tribalism lingers for kingdom's settled Bedouin," Reuters, retrieved $8^{\text {th }}$ May 2020, https://www.reuters.com/article/uk-saudi-bedouin/saudi-tribalismlingers-for-kingdoms-settled-bedouin-idUKTRE80O19Y20120125.

Al-Mubārakfūrī, Șafī al-Raḥmān (2007), Al-Raḥ̄iq al-Makhtūm, Qaṭar: Wizārah al-Awqāf wa-l-Shu'ūn al-Islāmiyyah.

Muslim, Imām Abul Hussain bin al-Hajjaj (2007), English Translation of Sahīh Muslim, Vol. 3, Riyadh: Darussalam. 
Journal of Al-Tamaddun, Vol. 15 (2), 2020, 57-70

Muslim, Imām Abul Hussain bin al-Hajjaj (2007), English Translation of Sahīh Muslim, Vol. 4, Riyadh: Darussalam.

Muslim, Imām Abul Hussain bin al-Hajjaj (2007), English Translation of Sahīh Muslim, Vol. 5, Riyadh: Darussalam.

Muslim, Imām Abul Hussain bin al-Hajjaj (2007), English Translation of Sahīh Muslim, Vol. 6, Riyadh: Darussalam.

Al-Qurțubī, Abū Abd Allāh Muhammad ibn Aḥmad Abī Bakr (2006), Al-Jāmic al-Ahkām al-Qur'ān, Vol. 10, Beirut: Al-Resalah.

Al-Qurțubī, Abū Abd Allāh Muhammad ibn Aḥmad Abī Bakr (2006), Al-Jāmical-Ahkām al-Qur'ān, Vol. 17, Beirut: Al-Resalah.

Al-Qurțubī, Abū Abd Allāh Muḥammad ibn Aḥmad Abī Bakr (2006), Al-Jāmic al-Aḥkām al-Qur'ān, Vol. 19, Beirut: Al-Resalah.

Sabini, John (1976), "The World of Islam: Its Nomads, Its Cities," retrieved $3^{\text {rd }}$ February 2020, https://archive.aramcoworld.com/issue/197603/the.world.of.islam-its.nomads.its.cities.htm.

As-Sallaabee, Ali Muhammad Muhammad (n.d.), The Biography of Abu Bakr as-Siddeeq, Riyadh: Darussalam.

Saunders, J.J. (2002), A History of Medieval Islam, London: Routledge.

Scarre, Christopher and Brian M. Fagan (1997), Ancient Civilizations, New York: Longman.

Al-Suhaylī, cAbd al-Raḥmān (1967), Al-Raẉ̣ al-Unuf fì Sharh al-Sìrah al-Nabawiyyah li-Ibn alHishām, Vol. 2, Cairo: Maktabah Ibn Taymiyyah.

Al-Suyūṭ̂̄, Jalāl al-Dīn (2002), Lubāb al-Nuqūl fì Asbāb al-Nuzūl, Beirut: Mu'assasah al-Kutub alThaqqāfiyyah.

Al-Ṭabarī, Ibn Jarīr (1994), Tafsìr al-Ṭabarī, Vol. 4, Beirut: Mu’assasah al-Risālah.

Al-Ṭabarī, Ibn Jarīr (1994), Tafsìr al-Ṭabarī, Vol. 6, Beirut: Mu’assasah al-Risālah.

Al-Tirmidzi (1988), Syama 'il Muhammadiyya, Beirut: Dār al-Hadīth.

Al-Wālidī, Abū al-Ḥasan ‘Alī ibn Aḥmad (1991), Asbāb Nuzūl al-Qur'ān, Beirut: Dār al-Kutub alcIlmiyyah.

Wehr, Hans (1966), A Dictionary of Modern Written Arabic, Wiesbaden: Otto Harrassowitz.

Al-Wohaibi, Mohammed Abdullah (1981), Nomads in al-Hejaz Province: A geographic Study of Nomads near the City of Taif, Master Thesis. Oklahoma State University. 